\title{
Autophagy in Amiodarone induced Lung Fibrosis: A Close Look
}

\author{
Poornima Mahavadi*1,2 \\ ${ }^{1}$ Department of Internal Medicine, Justus-Liebig University, Giessen, Germany \\ ${ }^{2}$ Universities of Giessen and Marburg Lung Centre (UGMLC), Member of the German Centre for Lung Research (DZL), Giessen, Germury
}

*Corresponding author: Poornima Mahavadi, Department of Internal Medicine, Germany

\section{ARTICLE INFO}

Received: 幽 May 27, 2019

Published: 嵊 June 06, 2019
ABSTRACT

Citation: Poornima Mahavadi. Autophagy in Amiodarone induced Lung Fibrosis: A Close Look. Biomed J Sci \& Tech Res 18(4)-2019. BJSTR. MS.ID.003182.

\section{Autophagy}

Autophagy is a fundamental lysosome-dependent cellular quality control mechanism [1]. The process involves orchestrated interactions of several autophagy related gene (atg) products that help in sequestration of cargo into characteristic double-membrane structures called autophagosomes [1,2]. Lipidated from of microtubule-associated proteins 1A/1B light chain 3B (MAP1LC3B/ LC3B) marks the autophagosomes which then fuse with lysosomes to degrade their cargo. Autophagy primarily aims at cell survival but its deregulation results in the activation of several cell death pathways that play a pathomechanistic role in the development of several pathologies [3]. Such dysregulated autophagy has been indicated in the pathology of Diffuse Parenchymal Lung Diseases (DPLDs) [4-8], a group of lung pathologies that affect the pulmonary interstitium, alveolar epithelium and capillary endothelium [9].

\section{Amiodarone}

Amiodarone (AD) induced pulmonary fibrosis falls under the category of drug induced form of DPLDs [9]. AD is an antiarrhythmic drug and possesses typical class III VaughanWilliams properties $[10,11]$. It is extremely effective in treating different kinds of arrhythmias but is a drug of last choice because of its contraindications. Pulmonary toxicity, especially confluent lung fibrosis is one of the severe side effects of amiodarone ultimately resulting in the death of patients. Patients receiving $\mathrm{AD}$ as low as $200 \mathrm{mg}$ per day also develop severe pulmonary complications. Therefore, it is prescribed to treat atrial fibrillation strictly in the absence of pre-excitation and only when other agents become unsuccessful [12]. Characteristic Alveolar Epithelial Type II Cell (AECII) hyperplasia and foamy macrophages are typical cellular features of $\mathrm{AD}$ induced lung fibrosis. Additionally, $\mathrm{AD}$ results in AECII apoptosis in patients as well as in animals [13-15]. Appealing studies have shown that $\mathrm{AD}$ gets enriched in lysosomes and results in multilamellar body accumulation in several cell types $[16,17]$. Supporting this concept, we also showed that in response to AD, lamellar body membranes in AECII are closely connected with autophagosomal structures [8].

\section{Role of Autophagy in AD Induced Lung Fibrosis}

Both $\mathrm{AD}$ and its derivate dronedarone induce autophagy [18]. We and others have shown that AD promotes and increases autophagy flux and thereby apoptosis of alveolar epithelial cells in vitro. Supporting this, inhibition of autophagy firstly in vitro by LC3B gene silencing rescued Mouse Lung Epithelial Cells (MLE12) from AD induced apoptosis [8]. In addition and of note, an elegant study by Uhal \& colleagues that focused on the role of angiotensin system antagonists in $\mathrm{AD}$ induced lung fibrosis showed that rats treated with $\mathrm{AD}$ followed by treatments with the angiotensin converting enzyme inhibitor captopril as well as the angiotensin receptor antagonist losartan significantly reduced AD induced alveolar epithelial cell apoptosis as well as alveolar wall collagen accumulation [19]. It is noteworthy that both these drugs are reported to inhibit autophagy $[20,21]$. Although not directly proved, it may be speculated that the attenuation of $\mathrm{AD}$ induced alveolar epithelial cell apoptosis and thereby lung fibrosis by these drugs may at least in part act via autophagy inhibition.

On the other hand, Transcription Factor EB (TFEB), known as a master gene for lysosomal biogenesis is activated and translocated to the nucleus upon AD treatment. Further data indicated that 
the overexpression of TFEB proved to be protective towards $\mathrm{AD}$ induced phospholipid accumulation [22]. One intriguing study by Lee\& colleagues showed cell and dose specific effects of AD on autophagy. A further activation of autophagy by rapamycin rescued $\mathrm{AD}$ induced goblet cell hyperplasia, airway inflammation, and mucin secretion in rats.

\section{Conclusion}

It is now well-documented that $\mathrm{AD}$ induces exaggerated autophagy, alveolar epithelial cell stress and apoptosis and subsequent lung fibrosis. It may be alluring to take the next steps towards therapeutic targeting of this pathway but in view of the multifaceted functions of autophagy, a concrete understanding of the mechanisms behind dysregulated autophagy in AD induced lung fibrosis are still warranted to design therapeutic interventions that fine tune the autophagy pathway in this disease.

\section{References}

1. Klionsky DJ, Emr SD (2000) Autophagy as a regulated pathway of cellular degradation. Science 290(5497): 1717-1721.

2. Levine B, Klionsky DJ (2004) Development by self-digestion: Molecular mechanisms and biological functions of autophagy. Dev cell 6(4): 463477.

3. Codogno P, Meijer AJ (2005) Autophagy and signaling: Their role in cell survival and cell death. Cell Death Differ 2: 1509-1518.

4. Patel AS, Lin L, Geyer A, Haspel JA, An CH, et al. (2012) Autophagy in idiopathic pulmonary fibrosis. PloS one 7(7): e41394.

5. Bueno M, Lai YC, Romero Y, Brands J, St Croix CM, et al. (2015) PINK1 deficiency impairs mitochondrial homeostasis and promotes lung fibrosis. The Journal of clinical investigation 125(2): 521-538.

6. Ahuja S, Knudsen L, Chillappagari S, Henneke I, Ruppert C, et al. (2016) MAP1LC3B overexpression protects against Hermansky-Pudlak syndrome type-1-induced defective autophagy in vitro. Am J Physiol Lung Cell Mol Physiol 310(6): L519-L531.

7. Cabrera S, Maciel M, Herrera I, Nava T, Vergara F, et al. (2015) Essential role for the ATG4B protease and autophagy in bleomycin-induced pulmonary fibrosis. Autophagy. 11(4): 670-684.

8. Mahavadi P, Knudsen L, Venkatesan S, Henneke I, Hegermann J, et al. (2015) Regulation of macroautophagy in amiodarone-induced pulmonary fibrosis. J Pathol Clin Res 1(4): 252-263.

9. Maher TM (2012) A clinical approach to diffuse parenchymal lung disease. Immunol Allergy Clin North Am 32(4): 453-472.

\section{ISSN: 2574-1241}

DOI: 10.26717/BJSTR.2019.18.003182

Poornima Mahavadi. Biomed J Sci \& Tech Res

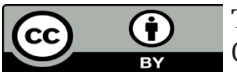

This work is licensed under Creative Commons Attribution 4.0 License

Submission Link: https://biomedres.us/submit-manuscript.php
10. Chang SN, Hwang JJ, Hsu KL, Tsai CT, Lai LP, et al. (2007) Amiodaronerelated pneumonitis. J Formos Med Assoc 106(5): 411-417.

11. Okayasu K, Takeda Y, Kojima J, Yoshizawa A, Kobayashi N, et al. (2006) Amiodarone pulmonary toxicity: a patient with three recurrences of pulmonary toxicity and consideration of the probable risk for relapse. Intern Med 45(22): 1303-1307.

12. January CT, Wann LS, Alpert JS, Calkins H, Cigarroa JE, et al. (2014) 2014 AHA/ACC/HRS guideline for the management of patients with atrial fibrillation: Executive summary: A report of the American College of Cardiology/American Heart Association Task Force on practice guidelines and the Heart Rhythm Society. Circulation. 130(23): 20712104.

13. Chiovato L, Martino E, Tonacchera M, Santini F, Lapi P, et al. (1994) Studies on the in vitro cytotoxic effect of amiodarone. Endocrinology 134(5): 2277-2282.

14. Bargout R, Jankov A, Dincer E, Wang R, Komodromos T, et al. (2000) Amiodarone induces apoptosis of human and rat alveolar epithelial cells in vitro. Am J Physiol Lung Cell Mol Physiol 278(5): L1039-L1044.

15. Mahavadi P, Henneke I, Ruppert C, Knudsen L, Venkatesan S, et al. (2014) Altered surfactant homeostasis and alveolar epithelial cell stress in amiodarone-induced lung fibrosis. Toxicological sciences 142(1): 285297.

16. Nagata N, Suematsu R, Yoshii C, Miyazaki H, Sueishi K, et al. (1997) Characterization of amiodarone pneumonitis as related to inflammatory cells and surfactant apoprotein. Chest 112(4): 1068-1074.

17. Somani P, Bandyopadhyay S, Gross SA, Morady F, Dicarlo LA (1987) Amiodarone and multilamellar inclusion bodies. Br J Clin Pharmacol 24(2): 237-239.

18. Morissette G, Ammoury A, Rusu D, Marguery MC, Lodge R, et al. (2009) Intracellular sequestration of amiodarone: role of vacuolar ATPase and macroautophagic transition of the resulting vacuolar cytopathology. Br J Pharmacol 157(8): 1531-1540.

19. Uhal BD, Wang R, Laukka J, Zhuang J, Soledad-Conrad V, et al. (2003) Inhibition of amiodarone-induced lung fibrosis but not alveolitis by angiotensin system antagonists. Pharmacol Toxicol 92(2): 81-87.

20. Xiao R, Teng M, Zhang Q, Shi XH, Huang YS (2012) Myocardial autophagy after severe burn in rats. PloS one 7(6): e39488.

21. Moon JH, Jeong JK, Hong JM, Seol JW, Park SY (2019) Inhibition of autophagy by captopril attenuates prion peptide-mediated neuronal apoptosis via ampk activation. Molecular neurobiology 56(6): 41924202.

22. Buratta S, Urbanelli L, Ferrara G, Sagini K, Goracci L, et al. (2015) A role for the autophagy regulator transcription factor EB in amiodaroneinduced phospholipidosis. Biochemical pharmacology 95(3): 201-209.

$\begin{array}{ll}\text { BIOMEDICAL } & \text { Assets of Publishing with us } \\ \text { RESEARCHES } & \text { - Global archiving of articles } \\ & \text { - Immediate, unrestricted online access } \\ & \text { - Rigorous Peer Review Process } \\ \end{array}$

